\title{
Taxation of the Self-employed in Poland and other EU Countries - a Comparative Analysis
}

\author{
Anna Krajewska (iD https://orcid.org/0000-0001-8895-6397 \\ Ph.D., Full Professor at the Warsaw University of Technology \\ College of Economics and Social Sciences, Warsaw, Poland \\ e-mail: anna.krajewska@pw.edu.pl
}

\section{Piotr Krajewski (iD) https://orcid.org/0000-0002-5377-9578 \\ Ph.D., Associate Professor at the University of Lodz \\ Faculty of Economics and Sociology, Department of Macroeconomics, Lodz, Poland e-mai: piotr.krajewski@uni.lodz.pl}

\section{Abstract}

The article aims to compare the taxation of the self-employed in Poland and other EU countries. We show that, for years, Poland has been at the forefront of EU countries with the highest self-employment rates. Our analysis indicates that many people in Poland chose the status of self-employed, guided by tax optimization. Due to large differences in the burden of income tax and social security contributions of people working full-time and choosing self-employment, there are strong incentives to move from employment to fictitious self-employment. Our study shows that this significantly affects the revenues of the state budget and social security fund in Poland.

Keywords: self-employment, taxes, labor market, public finances

JEL: E62, H24, J30 


\section{Introduction}

The share of self-employed people in total employment in Poland is growing rapidly. Poland is at the forefront of EU countries in this respect. The increase in the number of self-employed is often treated as a sign of entrepreneurship, which positively affects the economy. However, this phenomenon also has some weaknesses. The solutions adopted in the tax and contribution system may have a negative impact on the state of public finances, and in the longer term, also on the financial situation of self-employed workers. A self-employed person becomes a businessman, and therefore he has the option to choose the form of income taxation available for business. In Poland, the tax rate on business income is lower than the taxation on income from wage labor. This prompts some employees to move from a full-time job to fictitious self-employment.

The article aims to compare the taxation of the self-employed in Poland and other EU countries. We made a comparative analysis of the taxation of the self-employed and employees, and showed the consequences of self-employment for public finances in Poland. Additionally, Eurostat data were used to show significant differences in the taxation on self-employment in Poland and other EU countries.

\section{Self-employment. Problems with definition and measurement}

There is no definition of self-employment in any Polish legal act. International publications also indicate the ambiguity of this concept. Małgorzata Skrzek-Lubasińska (2017, p. 15), when reviewing the terminology related to self-employed workers used in scientific publications and public debate, lists nine Polish synonyms of this concept. There are also 12 synonyms in English: freelancer, small business owner, micro-business owner, home-based business, contractor or sub-contractor, independent contractor, consultant, free agent, solo-proprietor, solo-entrepreneur, and solopreneur.

Difficulties with the definition of self-employment result mainly from the fact that this category comprises very diverse people from various socio-professional groups, practicing various professions, with different levels of education, and who also receive very diverse income from their businesses. Freelancers (e.g., doctors, lawyers, journalists, and artists), as well as farmers, construction workers, security guards, and cleaners, are self-employed. It should also be considered that some self-employed people are naturally in this group due to their business (e.g., individual farmers), while others chose this form of business mainly to reduce tax burdens (income tax and social security contributions) or were "pushed" into it by employers seeking to reduce labor costs.

Difficulties in defining such a diverse category as self-employment translate into difficulties in measuring it statistically. According to the widest definition used in the In- 
ternational Labor Organization (ILO), the World Bank, and the Organisation for Economic Co-operation and Development (OECD), including individual farmers, there were nearly 33 million self-employed in the European Union countries in 2019. They were most frequently represented by freelancers (22.4\%), employees providing services and sales representatives (15.6\%), as well as craftsmen and retailers (15.3\%). Next were farmers (13.8\%), technical specialists, such as IT specialists, architects, and designers $(12.0 \%)$, and entrepreneurs/managers (11.9\%). The share of operators $(4.0 \%)$, people performing simple work (3.0\%), and those offering pastoral (spiritual guidance) support (1.8\%) was small. Compared to the self-employed structure observed in 2016, only the increase in the share of freelance professions is evident - at $20.9 \%$ at the time (Eurostat data).

The self-employment rate (the percentage of self-employed people in the total number of employees in the economy) varies considerably (Table 1). In 2019, it ranged from 8.0\% (Denmark) to 33.4\% (Greece). The self-employment rate has remained high for years in Greece and Italy (Żukowska 2017, p. 60), which is largely due to the nature of the economy of these countries (a large share of employment in tourism, gastronomy, the hospitality industry, small trade and crafts, as well as agriculture). The emergence of Romania in this group can be explained by changes in the labor market related to political transformation and a large share of the employed in agriculture. It turns out that Poland (with a 20.1\% share) is at the forefront of countries with the highest self-employment rates. With the EU average of $15.2 \%$, self-employment did not exceed $10 \%$ of the total employment in four countries (Germany, Sweden, Luxembourg, and Denmark).

Table 1. Self-employment in the EU (as \% of total employment in 2019)

\begin{tabular}{|l|c|l|c|}
\hline \multicolumn{1}{|c|}{ Countries } & \% of self-employed & \multicolumn{1}{c|}{ Countries } & \% of self-employed \\
\hline Austria & 11.9 & Italy & 22.9 \\
\hline Belgium & 14.0 & Latvia & 11.4 \\
\hline Bulgaria & 11.8 & Lithuania & 11.5 \\
\hline Croatia & 12.0 & Luxembourg & 8.5 \\
\hline Cyprus & 13.2 & Malta & 14.0 \\
\hline Czech Republic & 16.8 & Netherlands & 16.6 \\
\hline Denmark & 8.0 & Poland & 20.1 \\
\hline Estonia & 10.6 & Portugal & 16.7 \\
\hline Finland & 13.2 & Romania & 24.8 \\
\hline France & 11.6 & Slovakia & 14.7 \\
\hline Germany & 9.8 & Slovenia & 15.0 \\
\hline Greece & 33.4 & Spain & 15.9 \\
\hline Hungary & 10.3 & Sweden & 9.6 \\
\hline Ireland & 14.9 & United Kingdom & 15.1 \\
\hline
\end{tabular}

Source: data.world.bank.org (accessed: 21.04.2020). 
It is also worth noting (as the data from Table 2 clearly show) that the share of self-employed people in total employment is closely related to the level of economic development of the country. In high-income countries, the self-employed usually account for a dozen or so percent of the total employed, while in underdeveloped countries, where the average income is low, the self-employed constitute even more than $80 \%$ of the total employed. The poor development of industry and services in these countries means that self-employment becomes a chance to earn a living. Thus, when a country reached a higher level of economic development, the share of self-employed people decreased. It is worth noting, however, that at the turn of the $20^{\text {th }}$ century, many factors appeared in economically developed countries (such as the development of new technologies and changes in the organization of work) that were conducive to the growth of self-employment (Wennekers et al. 2010).

Table 2. Self-employment in selected groups of countries in 2019 (as \% of total employment)

\begin{tabular}{|c|c|c|c|}
\hline Groups of countries & $\%$ of self-employed & Countries & $\%$ of self-employed \\
\hline $\mathrm{EU}$ & 15.2 & Chad & 93.3 \\
\hline Eurozone & 14.7 & Afghanistan & 82.3 \\
\hline OECD & 15.0 & DR Congo & 77.1 \\
\hline \multirow{4}{*}{$\begin{array}{l}\text { Countries by income: } \\
\text { - high } \\
\text { - middle } \\
\text { - low }\end{array}$} & \multirow{4}{*}{$\begin{array}{l}12.3 \\
51.0 \\
82.5\end{array}$} & Cameroon & 76.7 \\
\hline & & Sub-Saharan Africa & 76.0 \\
\hline & & Angola & 70.3 \\
\hline & & Azerbaijan & 68.0 \\
\hline
\end{tabular}

Source: data.world.bank.org (accessed: 21.04.2020).

In turn, Eurostat BAEL-LFS data on natural persons conducting economic activity, but excluding the self-employed in agriculture, show that in the EU-28 countries, there were 23.4 million self-employed (2018), and their share in total employment in individual countries is shown in Table 3. This share ranges from $23.3 \%$ (Greece) and $20.2 \%$ (Italy) to $7.9 \%$ (Sweden), 7.3\% (Romania) and 6.8\% (Denmark). It is also evident that the percentage of employers and self-employed workers is generally higher in the new EU member states. In Poland, this percentage (12.1\%) is close to the EU-28 average of $11.4 \%$.

Table 3. Employers and self-employed in the EU (as \% of total employment excluding agriculture) in 2017

\begin{tabular}{|l|c|l|c|}
\hline \multicolumn{1}{|c|}{ Countries } & \% of self-employed & \multicolumn{1}{c|}{ Countries } & \% of self-employed \\
\hline Austria & 8.8 & Italy & 20.2 \\
\hline Belgium & 12.5 & Lithuania & 8.5 \\
\hline Bulgaria & 8.9 & Luxembourg & 8.2 \\
\hline Croatia & 7.8 & Latvia & 10.0 \\
\hline Cyprus & 10.8 & Malta & 13.7 \\
\hline Czech Republic & 15.8 & Netherlands & 14.8 \\
\hline
\end{tabular}




\begin{tabular}{|l|c|l|c|}
\hline \multicolumn{1}{|c|}{ Countries } & \% of self-employed & \multicolumn{1}{c|}{ Countries } & \% of self-employed \\
\hline Denmark & 6.8 & Poland & 12.1 \\
\hline Estonia & 9.5 & Portugal & 11.8 \\
\hline Finland & 10.0 & Romania & 7.3 \\
\hline France & 9.7 & Slovakia & 14.8 \\
\hline Greece & 23.3 & Slovenia & 10.1 \\
\hline Germany & 8.7 & Spain & 14.8 \\
\hline Hungary & 8.7 & Sweden & 7.9 \\
\hline Ireland & 11.1 & United Kingdom & 13.7 \\
\hline
\end{tabular}

Source: Eurostat, as cited in Cieślik 2019, p. 14.

The Central Statistical Office (CSO) data $(2006,2009,2017)$ show that the number of self-employed people is growing rapidly in Poland. According to the CSO definition, self-employed workers are natural persons who conduct non-agricultural economic activity and who do not employ employees based on an employment relationship. In 2006, there were 835,000 people with a status of self-employed, in 2009 the number exceeded one million $(1,014,000)$, and in the following years, the estimated number of self-employed persons increased rapidly. At the end of 2017, the CSO registered 1.2 million self-employed, and at the end of 2018, 1.3 million. Thus, compared to the previous year, the number of self-employed had increased by $8.3 \%$, while since 2006 , the number had increased by over $30 \%$.

\section{Advantages and weaknesses of self-employment}

In the Polish economic and management literature (Puzio-Wacławik 2013; Szepelska 2013; Wiśniewski 2013; Jasińska-Biliczak 2015; Skrzek-Lubasińska, Sobiecki 2017), self-employment is treated as an important form of supporting entrepreneurship development in Poland. Self-employment is usually identified with entrepreneurship and innovation. The belief is often expressed that the most entrepreneurial and innovative self-employed will increase the scale of their activities, invest, introduce technical and organizational improvements, and create new jobs. Self-employment is also an affirmation of the financial independence of their abilities and skills, proof of trust in themselves and others, striving for independence and self-development, and deciding on the purpose of the activity, place, and time of work (Domański 2005).

Therefore, the growing number of self-employed in Poland is often assessed positively. It is pointed out that this leads to a more flexible labor market, lowering labor costs and reducing the so-called tax wedge (i.e., the difference between costs related to employee employment and net salary), which encourages employment growth and reduces the unemployment rate.

Cieślik (2019) clearly opposes this approach in an attempt to oppose common truths about entrepreneurship and self-employment deeply rooted in public awareness. He verifies the three widely disseminated views on this subject: 
1. The more entrepreneurs (people engaged in economic activities), the better for the economy and society. Justifying this hypothesis, the author indicates that the share of self-employed people depends on the level of economic development and cultural factors. Given the technical and organizational quality and the scale of operations of the Polish business sector, a further increase in the number of people running a business is not justified.

2. Newly created enterprises are established with a view to developing and employing employees in the future. In Cieślik's (2019) opinion, less than 10\% of those setting up a business every year are likely to become employers in the future. This is indicated not only by observations regarding Poland, but also by trends occurring in other countries.

3. Incentives to start new businesses lead to economic recovery and GDP growth. It turns out, however, that concessions and preferences for self-employed and micro-entities do not bring the expected results due to the unstable form of this activity conducted on a small scale, with low technical equipment, low productivity, and limited development ambitions of the owners.

The arguments presented above indicate that supporting self-employed and micro-entities in Poland is based more on ideological and doctrinal considerations than on substantive analysis of reality. In practice, entrepreneurs are the largest beneficiaries of the transition of employees employed under an employment contract to self-employment. By using the services of such an employee, they can significantly reduce their labor costs, as they are not burdened with social security contributions and obligations to the employee under the Labor Code (notice period, vacation and health leave, and ensuring working conditions in accordance with health and safety at work requirements). At the same time, the employee receives a higher salary, which in the short run can be positively assessed from a motivational point of view.

It should also be remembered that the decision on self-employment has some negative consequences, which include:

- Loss of entitlements and privileges guaranteed by the Labor Code, such as vacation, health, maternity, and sick leave, social benefits, and work security;

- Business risk and prospects not only for a higher, but also for a lower income, incurring losses and a threat of bankruptcy;

- Running a business necessitates incurring costs that reduce income;

- Lower social security contributions paid by self-employed people mean lower pensions in the future.

Analysis of the impact of self-employment on public finances, i.e., the revenues of the state budget is missing in the relevant literature. And here emerge two sensitive issues.

First of all, self-employed workers are a very diverse group from the point of view of tax law. They can pay income tax in the form of a tax chart, registered lump sum, according to general principles (progressive tax with rates of 18 and 32\%, currently 17 and $32 \%)$, or choose a flat tax (19\%). The lack of an unambiguous definition of self-em- 
ployment, combined with a great choice of forms of taxation, can lead to tax optimization beneficial for the taxpayer, but not necessarily in line with legal requirements, budget needs, as well as social justice requirements. This happens when people who perform the same professional duties pay different taxes just because they choose a specific formal professional status.

Secondly, the self-employed pay lower social contributions than employees employed under an employment contract. This reduces the income of the Social Security Fund on an ongoing basis and means that with the current structure of employed, self-employed, and pensioners, it is necessary to finance the Social Security Fund from the state budget. Much more serious, however, are the long-term effects of low self-employment contributions. In the future, self-employed workers will be threatened by low pensions and even the danger that the state will be forced to "contribute" to their minimum pensions. The deepening Social Security Fund deficit will also lead to shifting the tax burden onto future generations, i.e., onto employees who are not free to choose the tax rate and lower security contributions.

\section{Taxation of self-employed people in Poland}

Even before the beginning of the transformation process in Poland, the small private sector played a large role, much greater than in other countries of Central and Eastern Europe. The expansion of micro-enterprises dates back to 1990. The transition to a market economy enabled the liberation of entrepreneurship on a massive scale, and the Act on Freedom of Economic Activity (colloquially referred to as the Wilczek Act) gave great freedom to conduct business activity in accordance with the principle that "everything that is not prohibited is allowed." It should also be noted that the rapid pace of privatization and elimination of state-owned enterprises led to a sharp decline in employment. It was not only workers but also engineers and economists who were losing their jobs. Starting their own business, especially by entrepreneurial people, became an opportunity not only to survive a difficult period but also to start their own business and make a career in business.

In subsequent years, entrepreneurship in Poland developed quickly, taking various forms: self-employment, i.e., people without employees, micro-entities (enterprises employing up to 9 employees, including the owner of the company), as well as small and medium-sized enterprises.

From the beginning of the transformation to the present, successive governments have created tax preferences for entrepreneurs. The fact that entities conducting business activity are not excessively burdened with taxes is proved by the analysis conducted by the Ministry of Finance (Table 4). 
Table 4. Estimated amount of business taxation (2016)

\begin{tabular}{|l|c|c|c|c|}
\hline \multirow{2}{*}{ Type of taxation } & \multirow{2}{*}{ Number of taxpayers } & \multicolumn{3}{|c|}{ Taxes (PLN) } \\
\cline { 3 - 5 } & & Mean & Median & Amount \\
\hline Total & $2,232,830$ & 12,960 & 1,617 & 25.6 billion \\
\hline Lump sum & 474,448 & 3,033 & 420 & 1.4 billion \\
\hline Tax rates & $1,240,051$ & 3,375 & 920 & 3.5 billion \\
\hline Flat tax & 518,331 & 43,794 & 19,298 & 20.7 billion \\
\hline
\end{tabular}

Source: Chrostek et al. 2019, p. 42.

The data show that in 2016, the tax burden - both for entrepreneurs paying lump-sum tax and those paying tax according to tax rates - was very low; on average, it amounted to slightly over PLN 3,000 per year ${ }^{1}$. It is also worth paying attention to the median tax burden, which amounted to PLN 420 for the lump-sum taxpayers and PLN 920 for taxpayers who choose general principles (tax rates). This means that almost half of these businessmen paid minute income taxes, and a significant part of them did not show their income. Almost $78 \%$ of people running a business fit into these two groups (lump sum tax rate and general principles).

The remaining $22 \%$ of businessmen chose a flat tax, i.e., they pay their taxes at a rate of $19 \%$. It is also worth noting that they are businessmen with high average incomes (PLN 43,794). The large diversity of income of this group of businessmen is demonstrated by the median, which is more than half lower than the mean income (PLN 19,298). This group of businessmen probably also includes many self-employed workers.

It is lower taxation of business income than taxation of income from work that encourages many high-income people to optimize taxation by switching to fictitious self-employment. The calculations of Cieślik (2018) regarding an employee earning PLN 15,000 per month indicate that by moving to self-employment, an employee may have a net income higher by even PLN 50,000 per year. It should be added that this is not the only financial effect of the transition from full-time employment to self-employment. A self-employed person, by obtaining the status of entrepreneur, can deduct tax-deductible costs, such as the costs of buying and running a car, computer, and telephone, among others, seriously reducing taxable income.

It is worth referring to the analysis conducted at the Ministry of Finance. Chrostek et al. (2019) show that taxes on business activities are degressive, while taxes on employees employed under employment contracts are essentially flat. The tax rate on employment contracts (personal income tax + contributions in relation to taxable income plus social security contributions of the employee and employer) is approximately $37 \%$, and it is similar in different income brackets. Effective taxation of individual business activity is regressive - it decreases with an increase in annual income, from $53 \%$ (with an annual gross income of PLN 10-25,000) to $24 \%$ (with an annual income

1 Low tax burden for entrepreneurs who file their tax returns according to general principles shows that taxpayers make maximum use of the allowances due to them, the option to file a joint tax return with their spouses, and of the relief for children. 
of PLN 100-200,000). The high burden on low-income entrepreneurs is the result of the lump sum social security contributions (PLN 1,121.52 per month in 2016).

How can such unequal taxation of labor and business be explained on the basis of economic theory and practice of the transformation period?

For over 200 years, two alternative theories that justify the collection of taxes have been considered in the public finance literature, the benefit/equivalence principle and the ability-to-pay principle.

The benefit/equivalence principle assumes that taxpayers should contribute to financing the state's activities to the extent to which they use them. This rule originates from a time when the state was seen mainly as a "night watchman," and it was assumed that the less the state interfered in the economy, the better. Therefore, taxes should be low and harm entrepreneurs as little as possible. On the other hand, the principle of tax ability/tax efficiency assumes that taxes should be collected from those who are able to cope with such burdens ("equality of an offering", tax progression, tax reliefs, and exemptions). The adoption of this principle as the basis for collecting taxes is most often justified by the requirements of justice, fiscal efficiency, and the need to use taxes to achieve various social purposes.

To put these principles concisely, it can be said that the proverb "Do unto others as you would have them do unto you" reflects the essence of the principle of equivalence. It should be added that this concerned the period when the State did not give much, but also people did not count on much from the state. For this reason, some modern economists believe that this principle should be rejected (Kosek-Wojnar 2012, p. 58). Adopting the ability-to-pay as a tax base, on the other hand, means accepting the Robin Hood principle, since those who are better off are more able to pay taxes, and at the same time, the state has to help them less, so it can spend the funds obtained from taxes on other purposes.

Many arguments indicate that from the beginning of the Polish transformation, the principle of equivalence/benefits played a dominant role in shaping tax rules and the state's attitude towards micro and small enterprises.

This was influenced by many circumstances:

1. The transition to a market economy was based on the liberation of entrepreneurship on a massive scale, and the Act on the freedom of economic activity provided great opportunities because "everything that is not prohibited is allowed."

2. The privatization of state-owned enterprises led to a large decrease in employment. For many people, starting a business on their own was a great opportunity.

3. In Poland, capitalism began to be built without family capitalists. Therefore, it was necessary to create favorable conditions to build domestic capital and Poland's own middle class through various forms of privatization and tolerating the development of the shadow economy.

4. Changes in the tax system were geared towards favoring private business activities and limiting the redistributive role of the state. 
Preferential taxation for small enterprises involves:

1. Creating the possibility to choose the most favorable form of business taxation - in addition to taxation according to general principles arising from the Personal Income Tax Act (tax progression - in the beginning, three rates, then two: 18 and 32\%), small businesses can benefit from preferential, simplified, and less fiscal forms of taxation in the form of a tax chart and a lump sum, and since 2004 they can also choose the flat-rate tax (19\%);

2. Low taxation of natural persons conducting economic activity (lower than for persons that earn a living from wage labor). Theoretically, this can be explained using the following arguments:

- A businessman's work is difficult, exhausting, with nonstandard working hours, and it is stressful, so it requires adequate remuneration;

- Running a business is associated with high risk; it may result in failure, and the business may have to be closed, which should also be considered;

- In the business process, the businessman involves not only his own work, inventiveness, and organizational skills, but also capital that, if used in another undertaking, would bring specific income (opportunity cost of capital);

- The lower the taxation of business activity, the higher the income the businessman has and can allocate to the development of the company, creating new jobs and introducing innovative solutions, which brings macroeconomic effects.

The liberal economic policy implemented in Poland favored businessmen not only by creating tax preferences for them, but also by creating other systemic solutions that support businesses, such as making the labor market more flexible, low and short-term unemployment benefits, low minimum wage, limiting the scope of social benefits, tolerating an extensive gray area that enabled some employers to avoid tax burdens, and tolerating a large proportion of employees employed on fixed-term contracts and mandate contracts.

However, is this approach to small business still valid after more than 30 years of building a market economy in Poland? Is it any wonder that the Ministry of Finance in 2019 attempted to limit fictitious self-employment by proposing to conduct an entrepreneur test? The Ministry assumed that an entrepreneur who is banned from acting for the competition and who works only for one contractor is not an entrepreneur, but only a self-employed person who performs the duties of a full-time employee, and their business is only a method of tax optimization. Vice Minister of Finance Filip Świtała, a participant in the tax workshops of Lazarski University and CASE (www.lazarski.pl (accessed: 10.09.2019)), assessed that this situation could affect 166,000 persons.

For many years, high-income employees switching to fictitious self-employment could, sometimes even significantly, reduce the tax and contribution burden and achieve an increase in income. For educated people with a good professional position, and who were sought after on the market, self-employment did not pose a real threat. And the choice of the status of self-employed was also beneficial for the company, as it made it possible to reduce labor costs. 
On the other hand, in the case of employees with low qualifications and a weak professional position, the transition to self-employment, although also beneficial for the employer, is not always as attractive to employees. More often, employees are "pushed" out of full-time employment to self-employment, and their weak and uncertain situation forced them to accept such an offer.

\section{The taxation of self-employment in Poland compared to other EU countries}

To show the specifics of taxing self-employed people in Poland, it is worth referring to the experience of other European Union (EU) countries. In accordance with the definition adopted in the European Commission, the income of people conducting independent economic activity (defined as self-employed) is treated as capital income. It is assumed that natural persons conducting small-scale business operations have the capital necessary to conduct a business activity, take risks, may employ wage earners, and pay contributions for themselves and their employees. At the same time, however, entrepreneurs must allocate part of their revenues to the development and modernization of the company. For this reason, small and medium-sized enterprises are taxed on preferential terms, and their taxes are treated as capital taxation in Eurostat statistics.

Taxes imposed on self-employed workers in the EU-28 constitute approximately $5 \%$ of budget revenues from taxes. However, their share in EU countries is very diverse (Table 5). In some countries, it does not even reach 1\%, e.g., 0.3\% in Slovakia, $0.4 \%$ in Estonia, $0.7 \%$ in Latvia and $0.8 \%$ in Croatia. In this ranking, Poland came first with an $11.6 \%$ share of this tax in budget revenues, and during some periods, it exceeded $12 \%$. A relatively high share (above average), but much lower than in Poland, was also recorded in Italy (7.7\%), Austria (6.5\%), the Netherlands (5.7\%), and Germany $(5.5 \%)$.

Table 5. Share of taxes imposed on self-employed workers in budget revenues from taxes (in \%)

\begin{tabular}{|l|c|c|c|c|c|c|}
\hline \multirow{2}{*}{ Countries } & 1995 & 2007 & 2017 & Ranking & \multicolumn{2}{c|}{ Difference } \\
\cline { 7 - 8 } & & & & 2017 & $\mathbf{1 9 9 5 - 2 0 1 7}$ & 2007-2017 \\
\hline Austria & 5.8 & 5.9 & 6.5 & 4 & 0.7 & 0.6 \\
\hline Belgium & 5.7 & 4.8 & 5.4 & 5 & -0.3 & 0.6 \\
\hline Bulgaria & 2.7 & 2.6 & 2.5 & 17 & -0.2 & 0.0 \\
\hline Croatia & - & 1.3 & 1.6 & 22 & - & 0.3 \\
\hline Cyprus & 2.0 & 1.3 & 1.6 & 23 & -0.4 & 0.3 \\
\hline Czech Republic & 4.1 & 3.7 & 2.9 & 14 & -1.2 & -0.8 \\
\hline Denmark & 2.5 & 2.2 & 2.0 & 19 & -0.5 & -0.2 \\
\hline Estonia & 0.5 & 0.7 & 0.4 & 27 & -0.1 & -0.3 \\
\hline Finland & 6.0 & 4.4 & 4.1 & 10 & -1.9 & -0.2 \\
\hline
\end{tabular}


Table 5. (continued)

\begin{tabular}{|c|c|c|c|c|c|c|}
\hline \multirow{2}{*}{ Countries } & \multirow{2}{*}{1995} & \multirow{2}{*}{2007} & \multirow{2}{*}{2017} & \multirow{2}{*}{$\begin{array}{c}\text { Ranking } \\
2017\end{array}$} & \multicolumn{2}{|c|}{ Difference } \\
\hline & & & & & $1995-2017$ & 2007-2017 \\
\hline France & 4.1 & 4.9 & 4.0 & 11 & -0.1 & -0.9 \\
\hline Germany & 5.1 & 5.5 & 5.4 & 6 & 0.3 & -0.1 \\
\hline Greece & - & 2.7 & 2.1 & 18 & - & -0.5 \\
\hline Hungary & 1.8 & 1.5 & 1.7 & 20 & -0.1 & 0.2 \\
\hline Ireland & 4.0 & 3.6 & 3.5 & 12 & -0.5 & -0.2 \\
\hline Italy & 7.3 & 8.3 & 7.8 & 2 & -0.5 & -0.5 \\
\hline Latvia & 0.1 & 0.7 & 0.7 & 26 & 0.6 & 0.0 \\
\hline Lithuania & 1.8 & 3.3 & 5.2 & 7 & 3.4 & 1.8 \\
\hline Luxembourg & 4.7 & 3.3 & 4.3 & 9 & -0.4 & 1.0 \\
\hline Malta & 4.0 & 3.4 & 2.7 & 16 & -1.3 & -0.6 \\
\hline Netherlands & 6.3 & 6.2 & 7.0 & 3 & -0.7 & 0.9 \\
\hline Poland & 7.1 & 12.8 & 11.4 & 1 & 4.3 & -1.4 \\
\hline Portugal & 3.1 & 1.5 & 1.7 & 21 & -1.4 & 0.2 \\
\hline Romania & 1.1 & 1.6 & 1.1 & 24 & 0.0 & -0.5 \\
\hline Slovakia & - & 1.1 & 0.3 & 28 & - & -0.9 \\
\hline Slovenia & 2.2 & 2.8 & 2.8 & 15 & 0.6 & 0.0 \\
\hline Spain & 7.0 & 4.8 & 4.9 & 8 & -2.1 & 0.1 \\
\hline Sweden & 1.3 & 1.5 & 1.1 & 25 & -0.2 & -0.4 \\
\hline United Kingdom & 4.2 & 13 & 3.2 & 13 & -1.0 & -0.9 \\
\hline EU-28 & - & 5.2 & 4.9 & $\mathrm{x}$ & - & -0.3 \\
\hline
\end{tabular}

Source: 1995 - European Commission 2011, p. 343; 2004-2016 - European Commission 2018, p. 229; 2019, p. 22.

The previously presented statistical data on the scale of self-employment show that self-employed in Poland constitute approximately 20\% of all employees. The share of taxes (income and health insurance contributions) in budget revenues from taxes is the highest in Poland (11-12\%).

At the same time, however, in countries with the highest self-employment rates recorded for years, i.e., in Greece and Italy, they contribute to the state budget to a much smaller extent - approximately $2 \%$ and $7-8 \%$, respectively. This means that people with very high incomes constituted a large proportion of the self-employed in Poland, for whom the transition to the status of self-employment made it possible to significantly reduce their tax burden. It can be assumed that this group includes those who chose to switch to self-employment mainly considering the reduction of the tax burden. This could apply to people who work on managerial contracts, highly qualified specialists, and members of free professions, who set up sole proprietorships and became entrepreneurs to reduce the tax burden.

The data in Table 6 show even more clearly the differences in the burden of income tax on natural persons. The tax burden on individuals was divided into four groups. Taxes imposed on: 1) employment, 2) self-employment (running businesses on their own), 3) transfers (old-age pensions, disability pensions, other social benefits), 4) capital 
income of natural persons. It turns out that in 2016, the share of employment-related tax revenues in Poland was the lowest. It constituted only $47.9 \%$ of income from PIT (compared to over 90\% in Estonia, Slovakia, and the Czech Republic), and the share of taxes paid by self-employed people was the highest, constituting $29.4 \%$ of total income from PIT. The share of tax revenues from self-employment in Germany (20.6\%), Austria (18.5\%), and the Netherlands (17.9\%) was also relatively high. The lowest was in Estonia, where it was only 0.7\%, while in several countries (Czech Republic, Sweden, Latvia, Slovenia, Slovakia, and Denmark), the taxes of self-employed people did not exceed 5\% of the tax burden on natural persons. The European Commission data show that in Poland, this situation has persisted for a long time. In 2004, taxes paid by self-employed people constituted $24.6 \%$ of income from PIT, while in 2007, it was even 30.4\% (European Commission 2018, p. 293).

Table 6. Structure of budget revenues from personal income taxes in 2016 (in \%)

\begin{tabular}{|l|c|r|r|r|}
\hline \multirow{2}{*}{ Countries } & \multicolumn{4}{|c|}{ Structure of budget revenues from PIT on account of } \\
\cline { 2 - 5 } & Employment & Self-employment & Transfers & Capital \\
\hline Austria & 59.5 & 18.5 & 19.3 & 2.7 \\
\hline Belgium & 74.8 & 13.6 & 15.6 & -4.0 \\
\hline Bulgaria & 88.5 & 8.6 & 0.0 & 3.0 \\
\hline Croatia & 75.0 & 5.1 & 2.4 & 17.5 \\
\hline Cyprus & 91.5 & 5.1 & 2.5 & 0.9 \\
\hline Czech Republic & 95.5 & 2.2 & 0.0 & 2.3 \\
\hline Denmark & 68.1 & 4.9 & 25.0 & 2.1 \\
\hline Estonia & 90.9 & 0.7 & 6.0 & 2.4 \\
\hline Finland & 61.8 & 7.2 & 23.6 & 7.4 \\
\hline France & 55.5 & 9.5 & 18.5 & 16.2 \\
\hline Germany & 72.2 & 20.6 & 4.4 & 2.8 \\
\hline Greece & 50.2 & 15.0 & 23.1 & 11.7 \\
\hline Hungary & 83.8 & 5.3 & 0.9 & 10.0 \\
\hline Ireland & 80.9 & 8.5 & 2.0 & 8.6 \\
\hline Italy & 53.9 & 14.5 & 28.0 & 3.6 \\
\hline Latvia & 83.3 & 3.4 & 10.7 & 8.6 \\
\hline Lithuania & 88.2 & 0.2 & 6.0 & 5.6 \\
\hline Luxembourg & 74.2 & 10.5 & 4.7 & 4.5 \\
\hline Malta & 73.1 & 7.0 & 17.9 & 1.9 \\
\hline Netherlands & 66.8 & 17.9 & 20.2 & 4.9 \\
\hline Poland & 47.9 & 29.4 & 17.6 & 5.1 \\
\hline Portugal & 57.3 & 5.6 & 24.8 & 12.3 \\
\hline Romania & 58.7 & 2.9 & 5.3 & 33.1 \\
\hline Slovakia & 94.9 & 4.0 & 0.0 & 1.1 \\
\hline Slovenia & 87.3 & 4.0 & 1.5 & 7.2 \\
\hline Spain & 67.1 & 8.9 & 12.5 & 11.5 \\
\hline Sweden & 2.3 & 19.7 & 9.4 \\
\hline
\end{tabular}


Table 6. (continued)

\begin{tabular}{|l|c|c|c|c|}
\hline \multirow{2}{*}{ Countries } & \multicolumn{4}{|c|}{ Structure of budget revenues from PIT on account of } \\
\cline { 2 - 5 } & Employment & Self-employment & Transfers & Capital \\
\hline United Kingdom & 74.5 & 10.1 & 2.7 & 12.7 \\
\hline EU-28 & 73.0 & 8.7 & 11.1 & 7.2 \\
\hline
\end{tabular}

Source: European Commission 2018, pp. 292-295.

The increase in the number of self-employed people in EU countries means that this model is becoming increasingly attractive for many professions. Unlike traditional professions such as doctors, dentists, or lawyers, you do not need to have any license to enter the self-employed group. Therefore, many new professions appeared in this group, related to IT and the so-called "creative" professions (computer graphic designers, designers, project managers, and specialists in marketing, finance, and management). In this context, self-employment is often promoted as a way to boost entrepreneurship and innovation, and to create new jobs. Self-employment also leads to greater autonomy, contentment, and independence in managing one's professional life. At the same time, however, more and more employers are "pushing" some employees into self-employment to save on social contributions and social benefits related to the employment relationship. And this means that the self-employed are most strongly represented in the lowest and highest income brackets.

When analyzing the data from Table 6, it is also worth noting that in Poland, a relatively large share of budget revenues from income taxes comes from transfers (17.6\% against $11.1 \%$ in EU-28). In some European Union countries (Bulgaria, the Czech Republic, and Slovakia), transfers are not taxed, while in six countries, they account for no more than $2 \%$ of budget revenues from PIT - from $0.9 \%$ (Hungary) to $2.7 \%$ (United Kingdom).

In Poland, the government has been introducing many facilitating conditions for small entrepreneurs for several years. It began in 2017 with a reduction in the corporate income tax rate to $15 \%$, and even to $9 \%$ in 2019 (for entrepreneurs with revenues of EUR 1.2 million; in 2020, this limit was raised to EUR 2 million). New reliefs came into effect from 2018 after the President of the Republic of Poland signed a package of laws referred to as the Constitution for Business (Act of 6 March 2018 - Entrepreneurs' Law, Journal of Laws 2018, item 646). The most important for the self-employed are exemption from social security contributions for the first six months and reduced contributions for the next two years.

People who started their business in 2020 can benefit from a special preferential social security contribution. For the first 24 months, it is calculated as $30 \%$ of the minimum wage (which has been net PLN 2,600 since 2020). The contribution calculated in this way, without the voluntary sickness contribution, is PLN 590.03, and 609.14 PLN with the voluntary sickness contribution. The solutions introduced by the government under the Constitution for Business and later were intended to increase the motivation to start one's own business instead of seeking or continuing a full-time job.

Earlier, tax and contribution solutions encouraged the transition to self-employment mainly of high-income employees; the low-paid were "pushed" by entrepreneurs, 
who thus reduced labor costs. Recent solutions create an incentive to set up their own business also for this group of employees. However, they are more exposed to risk and loss of income than highly qualified professionals, and in addition, low social security contributions mean a very low pension in the future.

The government explains such tax and contribution preferences for small businesses and self-employed people by the need to support entrepreneurship, which is the basis for the increase in the competitiveness of the Polish economy. Apart from the obvious political values indicating that the government is reducing the tax burden on entrepreneurs, such economic policy raises serious reservations. First of all - was it justified to encourage people to run their own business in 2019 and even at the beginning of 2020? There were employee shortages in the labor market, wages were rising, people could find employment in large companies, where labor productivity is higher, and the opportunity for promotion and higher wages are also better than in a small company or on precarious self-employment. The second remark concerns the effects of increased self-employment on the state budget and the social security fund. The increase in self-employment, motivated mainly by the desire to optimize tax burdens, means that budget revenues from personal income tax fall, and, to a much greater extent, they reduce the revenues of the social security fund, meaning a very low level of future pensions for the currently self-employed.

\section{Conclusion}

Changes in the labor market have led to the increased popularity of self-employment. Poland has been at the forefront of EU countries with the highest self-employment rates for years. Many factors point to the fact that in Poland, among the self-employed, there are many people that are in fact "fictitiously self-employed" and should be classified as employees.

Our analysis shows that many people in Poland chose the status of self-employed guided by tax optimization.

Due to large differences in the burden of income tax and social security contributions of people working full-time and choosing self-employment, there are strong incentives to move from employment to fictitious self-employment in Poland. Our study shows that this significantly affects the revenues of the state budget and social security fund.

Before the Great Recession, in the literature and in the media, the advantages of self-employment were exposed, i.e., freedom of action, greater prospects, higher income, and the possibility of choosing the optimal form of taxation and contributions. Less importance was attached to the risk associated with the transition to self-employment or the consequences of losing benefits under the Labor Code, such as holiday and sick leave. However, for the last decade, the European Economic and Social Committee has drawn attention to these problems, e.g., issuing Abuse of the status of self-employed 
(European Economic and Social Committee 2014). It contains, among others, proposals regarding the development of an unambiguous definition of self-employment applicable throughout the EU, which includes self-employed workers in occupational health, safety regulations, which ensure access to vocational training institutions, and the creation of service centers that care about their level of safety.

However, in Poland, in contrast to most EU countries, the consequences of the Great Recession were very mild. It was the coronavirus pandemic that made people aware of the role of labor security, which in the case of the self-employed is much lower than in the case of employees.

Thus, in our opinion, after the coronavirus pandemic, the role of labor security will increase relative to the differences between the net income of the self-employed and employees. It presumably will decrease incentives for fictitious self-employment. Nevertheless, there is still a need to reform the taxation of employees and self-employment in Poland, which would decrease incentives for fictitious self-employment and increase budget revenues.

\section{References}

Chrostek, P., Klejdysz, J., Korniluk, D., Skawiński, M. (2019), Wybrane aspekty systemu podatkowo-składkowego na podstawie danych PIT i ZUS 2016, Ministerstwo Finansów, "Opracowania i Analizy", 1.

Cieślik, J. (2018), Konstytucja biznesu: ulgi w ZUS, które moga szkodzić, "Rzeczypospolita", 15 April.

Cieślik, J. (2019), Samozatrudnienie w Polsce na tle tendencji ogólnoświatowych: wyzwania $w$ sferze polityki wspierania przedsiębiorczości i zabezpieczenia emerytalnego przedsiębiorców, “Studia BAS”, 2 (58), https://doi.org/10.31268/StudiaBAS.2019.10

Domański, T. (2005), Być i mieć. Przewodnik dla poszukujących własnej drogi, Wydawnctwo Tomasz Domański, MSM, Łódź.

European Commission (2011), Taxation trends in the European Union, Luxemburg. European Commission (2018), Taxation trends in the European Union, Luxemburg. European Commission (2019), Taxation trends in the European Union, Luxemburg. European Economic and Social Committee (2014), Abuse of the status of self-employed, OJ C 161, 6.06.2013, https://www.prawo.pl/akty/dz-u-ne-c-2013-161-14-14,68329678 .html (accessed: 15.02.2019).

Eurostat, https://ec.europa.eu/eurostat/web/lfs/data/database (accessed: 15.02.2019).

Jasińska-Biliczak, A. (2015), Problem samozatrudnienia - rola i miejsce mikroprzedsiębiorstw w gospodarce lokalnej, "Barometr Regionalny. Analizy i Prognozy", 13 (4), pp. 75-80, Wyższa Szkoła Zarzadzania i Administracji w Zamościu, Zamość.

Kosek-Wojnar, M. (2012), Zasady podatkowe w teorii i praktyce, PWE, Warszawa.

Puzio-Wacławik, B. (2013), Samozatrudnienie jako element systemowego wsparcia rynku pracy w Polsce, "Studia Ekonomiczne", 145, pp. 197-207.

Skrzek-Lubasińska, M. (2017), Dyskusja nad pojęciem "samozatrudnienie”. Problemy definicyjne i analityczne, [in:] M. Skrzek-Lubasińska, R. Sobiecki (eds.), Samozatrud- 
nienie. Konieczność czy wybór przedsiębiorczych, Oficyna Wydawnicza SGH - Szkoła Główna Handlowa w Warszawie, Warszawa, pp. 13-39.

Skrzek-Lubasińska, M., Sobiecki, D. (2017), Samozatrudnienie - konieczność czy wybór przedsiębiorczych, Oficyna Wydawnicza SGH - Szkoła Główna Handlowa w Warszawie, Warszawa.

Szepelska, A. (2013), Samozatrudnienie jako forma wspierania przedsiębiorczości, "Ekonomia i Prawo", XII (1), pp. 69-79, https://doi.org/10.12775/EiP.2013.006

Wennekers, S., Stel, A. van, Carree, M., Thurik, A.R. (2010), The relations between Entrepreneurship and Economic Development: Is It U-shaped?, "Foundation and Trends in Entrepreneurship", 6 (3), pp. 281-291, https://doi.org/10.1080/08985620701296318 Wiśniewski, J. (2013), Istota samozatrudnienia, "Studia z zakresu Prawa, Administracji i Zarządzania UKW", 3, pp. 35-59.

Żukowska, J. (2017), Samozatrudnienie - charakterystyka trendu w Polsce i innych krajach, [in:] M. Skrzek-Lubasińska, R. Sobiecki (eds.), Samozatrudnienie. Konieczność czy wybór przedsiębiorczych, Oficyna Wydawnicza SGH - Szkoła Główna Handlowa w Warszawie, Warszawa, pp. 1-167.

\section{Opodatkowanie samozatrudnionych w Polsce i w pozostałych krajach UE - analiza porównawcza}

Celem artykułu jest porównanie opodatkowania osób samozatrudnionych w Polsce z rozwiązaniami stosowanymi w innych krajach Unii Europejskiej. W artykule wykazane zostało, że polski rynek pracy cechuje się bardzo wysokim udziałem osób samozatrudnionych. Przeprowadzona analiza wskazuje, że istotną przyczyną tego popularności samozatrudnienia w Polsce jest optymalizacja podatkowa. Ze względu na duże różnice pomiędzy obciążeniami podatkowymi osób pracujących na etat i osób samozatrudnionych występują silne bodźce do prowadzenia fikcyjnego samozatrudnienia. W artykule ukazane jest, że zjawisko to silnie wpływa zarówno na dochody budżetu państwa jak i dochody Funduszu Ubezpieczeń Społecznych.

Słowa kluczowe: samozatrudnienie, podatki, rynek pracy, finanse publiczne 